\title{
Patience, presence and promise: A study of prophetic realism in Jeremiah 29:4-7
}

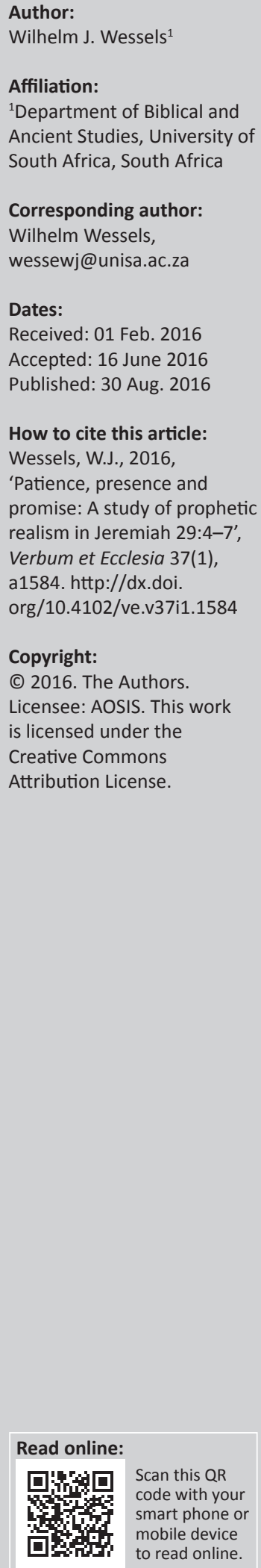

We tend to think of prophetic proclamation simply in terms of prophecies of doom or judgement and salvation or promise. Jeremiah is often regarded as a prophet of doom with rarely any positive proclamation. This view is contested by contending that Jeremiah was also a prophet of realism. He did not shy away from proclaiming prophecies of judgement but also embraced Yahweh's promises of restoration. Jeremiah's brief was to proclaim messages that will 'pluck up' and 'break down' and 'overthrow', but also 'to build' and 'to plant' (Jr 1:10). As much as this is true of Jeremiah's ministry, the focus of this article is on a neglected aspect of his prophetic ministry namely 'prophetic realism'. Jeremiah 29:4-7 is an example of prophetic realism as the prophet pastorally pays attention to the people of Judah in exile, calling on them to exercise patience whilst in exile and to contribute positively to their exilic society. This they should do whilst still holding onto Yahweh's promises. Amongst the many confusing prophetic voices to the exiles, Jeremiah's message is one of realism calling for patience, but also for constructive presence in their situation. Whilst Jeremiah's message exudes prophetic realism, he still emphasises that Yahweh's promise of restoration will play out in time (Jr 29:10-14).

Intradisciplinary and/or interdisciplinary implications: Traditionally prophecy is either regarded as judgement or promise. An argument is promoted for a third category of prophetic realism. This view is not only relevant for Old Testament science, but also for the disciplines of Systematic and Practical Theology. Jeremiah's prophetic realism compels researchers to broaden their views on what prophecy entails.

\section{Introduction}

When one reads the book of Jeremiah, the nature of the proclamation is overwhelmingly negative because of the many prophecies of judgement and doom. This can be explained because of Jeremiah's view that the people of Judah became disloyal to Yahweh and were morally corrupt. According to him, Yahweh will exercise judgement on the people through the hands of the Babylonian king and his armies. The proclamation of judgement ties in with Yahweh's calling of the prophet to proclaim messages with the purpose to 'pluck up' and 'break down' and 'to overthrow' (Jr 1:10; 12:14, 15; 18:7; 45:4).

This is however only one dimension of the prophet's proclamation. Although not the dominating theme of the book of Jeremiah, promises of salvation and a future for Judah and Israel always formed part of Jeremiah's proclamation. Besides the instruction by Yahweh to proclaim judgement, Jeremiah 1:10 testifies to the fact that he also had to proclaim messages 'to build' and 'to plant' (Jr $1: 10 ; 18: 9 ; 24: 6 ; 29: 5 ; 29: 28 ; 31: 4,5 ; 31: 28 ; 31: 40 ; 32: 41 ; 42: 10 ; 45: 4)$.

Although proclamation of doom or salvation ties in with the general idea of what Old Testament prophecy entails and many prophetic books are structured along the lines of judgement and salvation, the argument this article wants to present is that a neglected or unnoticed form of prophetic proclamation exists as part of Jeremiah's prophetic ministry, namely prophetic realism. By prophetic realism I mean a realistic observation and analysis of a situation or situations and a reasonable response to the state of affairs (cf. Moberly 2006:18). At times it implies to accept reality as is and responds to that immediate reality. Brueggemann (1998:257) uses the term 'political realism', but I prefer the term prophetic realism. It concerns more than just acknowledging political realities; it is facing reality from a point of theological or faith orientation and awareness of divine knowledge (cf. Moberly 2006:2-3).

As mentioned, prophets are known for proclaiming words of salvation and promises of a bright future or messages of judgement and doom. We very seldom, if ever, make room in our understanding of prophets for them to urge people to confront or settle for the reality they have to face. The aim of 
this article is to argue a case of prophetic realism by discussing Jeremiah 29:4-7. I am fully aware that a distinction should be made between prophetic speech and prophetic literature (cf. Weeks 2010:25-26; Nissinen 2004:17-31). The realism that Jeremiah 29 and in particular 29:4-7 reflect is then what the book of Jeremiah presents as prophetic speech to the 597 BCE exiles in Babylonia.

As a first step, chapter 29 will be divided into literary units before analysing 29:4-7 within the context of chapter 29 . This will be followed by an exposition of this short passage. The next step would be to argue a case for prophetic realism and finally reference will be made to other possible similar cases of prophetic realism. I should make it clear from the outset that I am not attempting to discuss whether in reality the call to accept the reality of the situation actually materialised and how matters panned out over time. ${ }^{1}$ I do however want to structure the discussion on prophetic realism around the themes of patience, presence and promise and what implications these three themes might have.

\section{Opposing prophetic voices}

An important aspect to keep in mind when discussing Jeremiah 29 is the frequent conflicts that raged between the prophet Jeremiah and opposing prophetic groups or individuals. The fact of the matter is that in Jeremiah 27-29 a number of texts are grouped together to form a cycle on conflict between various prophets (Osuji 2010:111-118; Overholt 1970:24-48). In chapter 27 Jeremiah symbolically carries a yoke on his neck to promote the message that it is better for the people of Judah to submit to the rule of Babylon. In opposition to his view of submission, a group of prophets referred to as 'prophets of salvation' pinned their hope on Egypt to come to the rescue of Judah. In chapter 28 we have a continuation of the symbol of the yoke, this time an iron yoke, but in this episode Jeremiah is at loggerheads with the prophet Hananiah who disputes Jeremiah's view of submission to the Babylonians. In similar fashion, Jeremiah 29 continues to display the conflict between Jeremiah and other prophets (Leuchter 2008:46-47). Some of the opposing prophets mentioned are Ahab, Zedekiah and Shemaiah. All three these prophetic figures are labelled by Jeremiah as false prophets who act without authority, live immoral lives and will receive punishment.

From the brief foregoing overview, it should be clear that the exposition of any passage from chapter 29 should be done by taking into account the overshadowing conflict between Jeremiah and opposing prophets (Davidson 2011:135). I will argue that in a chaotic world with many prophetic voices, the voice of Jeremiah with the message of realism should be acknowledged. The focus of this article will be mainly on Jeremiah 29:4-7. This will be done with a particular interest shown in the aspects of patience, presence and promise.

1.Some very insightful studies have been done on the living conditions in Babylonian exile and more studies of this nature can be expected in future. Cf. the research exile and more studies of this nature can be expected in future. Cf. the research
done by Albertz (1994:373-487); Smith-Christopher (2002:68); and from the done by Albertz (1994:373-487); Smith-Christopher (2002:68);
perspective of postcolonial readings Davidson (2011:151-171).

\section{Context}

Jeremiah 29 is a prophetic oracle presented in the format of letters. The fact that a prophetic proclamation is done by means of letters is very significant, because it allowed the prophet to communicate Yahweh's words in a location where he personally was not present. This is quite unique considering how prophetic proclamation is usually understood to take place. As Davidson (2011) remarks:

Textuality introduces a new dimension to prophecy, with the prophet's words mediated through letters and therefore filtered. The prophet and the source of prophecy exist one step removed from the hearing/reading community. (p. 147)

It seems that the letter in Jeremiah 29 does not comply with the way letters were constructed in ancient times. That this prophetic proclamation is presented as a letter might be a literary technique to illustrate that Jeremiah's message as true prophet of Yahweh was relevant and could reach even those in foreign countries. Fischer (2005:88) expresses the view that 'Die Brief-Gattung wird hier vielmehr als literarisches Mittel benützt, um den Austausch zwischen Heimat und Verschleppten anschaulich zu schildern'.

According to verse 1, a copy of a letter from Jeremiah residing in Jerusalem is sent to the leaders of the exiles, namely the priests, the prophets and also to all the people in Babylon. The letter is carried by two messengers whom King Zedekiah has sent as a delegation to King Nebuchadnezzar in Babylon. The delegates were Elasah a son of Shaphan and Gemariah the son of Hilkiah (Jr 29:3). The broader literary context of chapter 29 was already touched on by referring to the passages on conflict between prophetic figures in 27-29. The historical context reflected by the book of Jeremiah suggests that we are dealing with the Judean people exiled to Babylon in 597 BCE. These exiles consisted of the people that were taken captive in Jerusalem with King Jehoiachin and his mother (cf. Jr 2:24-30). Although Jeremiah wrote from Jerusalem, he disputes the legitimacy of some of the prophets who acted as self-appointed messengers from Yahweh. It seems that one of the main contentious issues was how long the exiles of Judah would remain in Babylonia. It is against this background that the section 29:4-7 will be analysed.

\section{Structure, analysis and exposition of Jeremiah 29:4-7}

In this section a discussion will be offered with regards to the structure of Jeremiah 29 and as well as an analysis and exposition of 29:4-7 in terms of prophetic realism.

\section{Structure}

Chapter 29 can be divided into the following two main sections: 29:1-23 and 29:24-32 (Osuji 2010:231). Jeremiah 29:4-23 probably contains the letter to the exiles (cf. Fretheim, 2002:399-400; Huey Jr 1993:253). These two main sections can be subdivided into $29: 1-3 ; 4-7 ; 8-9 ; 10-14 ; 15-19 ; 20-23$ and 24-32. For the purpose of this article, the focus will be on 
29:4-7 that forms part of the first of the two main sections in chapter 29. Verses 4-7 and 10-14 focus on hope and restoration, whilst verses 8-9 and 15-23 are concerned with the problem of true and false prophecy amongst the exiles (Diamond 2003:586-587). Both Jeremiah 29:15-19 and 20-23 deal with instances of prophetic conflict, whilst the longer section 24-32 display a clash between Jeremiah and a selfappointed prophet Shemaiah in Babylon who took the liberty to write letters to some priests in Jerusalem.

The Masoretic Text (MT) of Jeremiah 29 poses many textcritical challenges, particularly when it is compared to the Septuagint translation (LXX). One of the main sections missing in the LXX is verses $16-20$. Some scholars consider these verses to be secondary because they relate to the Jerusalem community whilst the letter is addressed to the Babylonian exilic community (cf. Rudolph 1968:186-187; Weiser 1969:255). However, there seems no reason why the letter to the exiles could not speak to the situation in Judah as well, since their fate was closely linked (cf. Lundbom 2004:345). There are many differences between MT and LXX in this section. A detailed study of the two versions however cannot be entertained within the scope of this article (cf. Carroll 1986:564-565). The longer version of the MT, when compared to the LXX, is perhaps an indication of redactional work done by the Jeremiah tradition to affirm Jeremiah's authority as the true prophet (Diamond 2003:587). Lundbom (2004:346) regards the second letter to Shemaiah as part of a longer letter, therefore the letter Jeremiah 29 is not preserved in its original form.

Most scholars will agree that it is a multi-layered text which makes it difficult to analyse. On the one hand there are the historical critics who approach the text with clinical analytical logic, which allows little room to constructively work with the text (cf. Carroll 1986:555-568; Rudolph 1968:184-188). It leaves the interpreter with more questions than answers and raises the question as to whether the almost cynical logic the text is submitted to, does justice to what the text intended to communicate. This is not to deny that at times it is difficult to determine how the various sections and layers of the text interact, but calls for a constructive approach to the text to, in some way, make sense of the content. It is therefore not a plea for a naive reading of the text, but for a constructive reading to grasp what the tradition responsible for preserving the text, wanted the text to communicate to future readers.

\section{Analysis of Jeremiah 29:4-7}

Verse 4 commences with the messenger formula 'Thus says Yahweh of hosts, Elohim of Israel'. This makes it clear from the outset that the prophet wants to communicate that his letter contains authentic words from Yahweh. The letter is presented in the form of an oracle (Carroll 1986:552; Davidson 2011:136). This verse also clearly indicates who the addressees are for whom the words of Yahweh are meant. It is addressed to all the people who were exiled from Jerusalem, including the leaders in the community. It is explained in a relative clause that the first person singular, referring to Yahweh, is responsible for the exile of the people from Jerusalem to
Babylon. Verse 4 commences with a 3rd person, but then

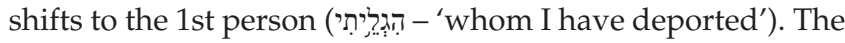
Biblia Hebraica Stuttgartensia and also the Syriac translation suggest a change to read 'who have been deported'. Bright (1965:208) finds this unnecessary and argues that such shifts often occur in prophetic addresses (also Thompson 1980:546). The LXX and the MT correspond in this regard.

In the next three verses (5-7) the content of the message from Yahweh to the exiles in Babylon is spelled out. This interestingly is done in no less than 11 verbs in imperative form and two verbs jussive ${ }^{2}$ in meaning in verse $6 .^{3}$ All of these verbs demand the addressees of the letter to take action. It is also noticeable in verses 5 and 6 that there are five instances in which the verbs function as word pairs, two in each of the mentioned verses. They are as follows:
Build houses
Plant Gardens
and settle down
Take wives and eat their produce and have sons and daughters
Take wives for your sons and give your daughters in marriage They should bear sons and daughters and multiply

Verse 6 ends with a negative adverb (אֵ) followed by the qal imperfect 2nd person masculine plural jussive in meaning of the verb מעט: do not decrease!

There is an interesting progression to be noted in verses 5 and 6. It begins with the building of houses, the settling in these houses with the next logical step being getting married and having children. But the progression does not stop here, for the next step is for the offspring to then get married and have children which will result in the multiplication of the exiles and finally to maintain the numbers of the population.

Verse 7 also has two imperative verbs. The first clause

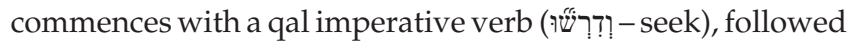
by the direct object in construct with the noun 'the city'4 meaning (אֶּ - 'the shalom of the city'. The city referred to here is Babylon and the suggested change to 'the land' as the LXX have is, is not correct in this context. This first clause in verse 7 is followed by a relative clause similar to the one in verse 4 . The first person singular subject of the

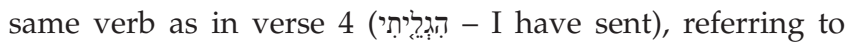
Yahweh, again indicates that Yahweh is responsible for the fact that the people are in exile. This clause ends with the

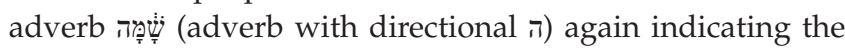
city Babylon. The second last clause of verse 7 starts with a

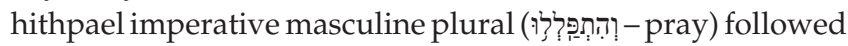
by a preposition with a 3rd person feminine singular suffix (בעעידָה) referring to the city of Babylon. ${ }^{5}$ The command is that the exiles should pray to Yahweh on behalf of Babylon. This

2.The jussive is used to express a definite expectation or strong desire that something should happen, cf. Kautzsch (1910:130-131, 317).

3.In the LXX the clause 'and let them give birth to sons and daughters' is lacking.

4.The LXX has 'the land' instead of 'the city'.

5.Lundbom (2004:351-352) argues that the reference to the city does not necessarily refer to Babylon, since the exiles settled in many different regions in Babylonia. Although it is true that they settled in different regions, in this particular context Although it is true that they settled in different regions, in this particular context
Babylon is meant because verse 4 (Babylon explicitly referred to) corresponds with Babylon is meant because verse 4 (Babylon explicitly referre
verse 7 where the reference to the city has a definite article. 
clause is then substantiated by a final clause in verse 7 introduced with כִ explaining the reason why they should pray. The כִ is followed by the noun שָׁ with the 3rd person feminine singular suffix, indicating again the city Babylon. The clause is concluded by a 3rd person singular form of the verb היה 'to be', followed by the preposition ?̧ with 2nd person masculine plural suffix - referring to the exiles - and again

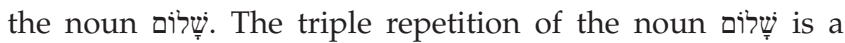
strong indicator of the importance of this noun in the context of the section Jeremiah 29:4-7 and also chapter 29. This reference to the city Babylon in verse 4 and then again the four references to the same city in verse 7 , clearly place the focus on the city Babylon in this passage. Whereas the action verbs in verses 5 and 6 focussed on what the people of Judah in exile should do with regards to their own existence, in verse 7 the focus is on what the exiles should do with regards to the city Babylon. But the interesting fact is that if they focus on the circumstances with regards to Babylon, it will again be beneficial for their own circumstances and existence.

\section{Exposition in terms of the idea of prophetic realism}

Jeremiah 29:11 is one of the well-known verses from the book and is often quoted by readers for all sorts of reasons. It reads as follows: 'For surely I know the plans I have for you, says the LORD, plans for your welfare and not for harm, to give you a future and hope'. This verse is usually used in isolation and out of context and serves as an example of how Bible readers seek out prophetic proclamations that fall within the category of salvation prophecies. However when one reads this verse within the broader context of chapter 29, perhaps more particularly within the context of $29: 1-14,{ }^{6}$ a totally different picture emerges. Jeremiah 29:8-9 alerts one to a dispute raging between the prophet Jeremiah and other prophetic groups or individuals. In this passage Jeremiah refers to prophets amongst the Babylonian exiles who act without authorisation or commission from Yahweh. Jeremiah warns the exiles not to regard the dreams of the so-called prophets as revelations from Yahweh. It seems that the dispute between Jeremiah and these prophets concerns the issue of the duration of the Babylon exile. In Jeremiah 29:10 Jeremiah mentions a stay of 70 years in exile, which implies a lengthy stay in the foreign country. The dispute over the length of time that the people of Judah would spend in Babylonian exile already raged in the conflict between Jeremiah and the prophet Hananiah in chapter 28:3-4. According to Hananiah, in two years the people in Babylonian exile will be resettled in Judah and with them the Temple utensils will also return to Jerusalem. It is in light of this dispute between the various prophets that I want to argue the case of prophetic realism.

6.1 do not agree with Carroll (1986:553) who regards $29: 10-14$ as a secondary addition placed in this position to counter the idea of permanent residency promoted in 29:4-7. The point I argue in this article is that at the time of the announcement of 29:4-7. The point largue in this article is that at the time of the announcement of verses 4-7, setting was the realistic thing to do since restoration was future music at this stage. Brueggemann (1998:260) expresses the view that the two units of verses 5-9 and verses 10-14 form two essential aspects of the Jeremiah tradition.

\section{Patience}

The argument presented here is not that the prophet Jeremiah denies the promise of the future return for the Judean exiles to their own country, but rather to acknowledge the reality of the situation that they will have to prepare themselves for a lengthy stay in Babylon. They have to accept the reality that Nebuchadnezzar serves as an agent of Yahweh at this stage in their history (Leuchter 2008:47). Jeremiah's call to the people therefore in the first place implies that they will have to exercise patience until the time comes that the promise of their return to their homeland will be fulfilled. However, in the light of 29:4-7 the exercise of patience does not imply a wait and see attitude, but patience whilst they constructively engage in their living conditions in Babylon. As was discussed in the section on the analysis of 24:4-7, Yahweh commanded the people to act constructively to normalise their living conditions and establish themselves in the society to safeguard not only their current living conditions, but also their future. The prophetic word of realism was that they had to accept the fact that they would spend a lengthy time in the foreign country and that they should patiently establish themselves as a community by building a future. They had to build houses and live in these houses, but more than that, they had to work the land in order to provide food for their own subsistence. The use of the familiar terminology 'to build' and 'to plant' should not escape our attention. This instruction once again makes it clear that they should not rely on the predictions of the prophets who created the expectation that they will soon be restored in the homeland to build and plant there. Jeremiah's proclamation counters that of the opposing prophets (McEntire 2015:167). They should settle and patiently work to secure their immediate future.

The exiles were also commanded to do what was natural for any community to survive by getting married, having children, multiplying and thereby safeguarding their future as a community. They had to patiently establish themselves as a community in the foreign country, patiently let the community become self-sufficient and patiently do the things that would secure their future as a people.

\section{Presence}

The second issue this article wants to discuss is the aspect of presence. It is not far-fetched to assume that for the inhabitants of the Babylonian community the presence of the Judean exiles was a reality they had to deal with or even benefit from in terms of labour (Perdue \& Carter 2015:78). However, the presence of the Judean exiles would have become more noticeable once they started to act on the command of Yahweh to establish themselves as a more permanent community within the Babylonian society. Merely the building of houses would have signalled the intention of the people to become a more established community.

Another matter that would have attracted the attention of the Babylonian people is the cultivation of the land and the produce that would result because of the working of the 
land. If this endeavour came to fruition it would have economic implications for the society as a whole. Economics have a way of enforcing people's presence in significant ways. On the one hand it could lead to a situation of less economic dependence on the local economic infrastructure when a community becomes self-sufficient. If their agricultural endeavours were successful, the exiles could even positively contribute to the economics of the city Babylon. On the other hand it could be seen as a threat when it leads to competition in the marketplace with negative effects on the local agricultural markets.

Growing numbers would surely also have alerted the local population in Babylon to the presence of the Judean people. A more established and growing community in Babylon would without doubt have social and cultural ramifications (Davidson 2011:162). It is a fact that intercultural exposure leads to mutual influence on identity and social conventions. It can be interpreted as an enrichment of one's own culture or seen as a threat to a group's unique customs and habits. Integration in the Babylonian society implied social interaction which opened up the possibilities of intermarriage (Ames 2011:184). Another such crucial matter would be religious convictions and practices. The people of Israel were defined by the conviction that they were the chosen people of Yahweh and that they had the status of being a covenant people. The people residing in Babylon could have felt that the presence of a people who form their identity on their relationship with a covenant God might cause a threat if they have missionary intentions. From the Judean exiles point of view, they again ran the risk that exposure to Babylonian religious practices could contaminate their unique relationship with Yahweh as his people. This could lead to a situation where the exiles isolate themselves from the broader society in Babylon and in that sense became an unknown entity that poses a threat to the Babylonian society because of secrecy and exclusivism. As Davidson (2011:158) has mentioned, the series of imperatives in 29:5-7 concern economic, demographic and religious aspects of life in the diaspora (also Thompson 1980:546). In verse 7 the religious aspect of their presence in Babylon will be discussed.

Jeremiah 29:7 is an important verse for the discussion on the issue of the presence of the Judean exiles in Babylon. This verse calls for constructive presence in the city Babylon. The key concept in this verse is the notion of שָׁi. The meaning of this noun is not that easy to define as is clear from the variety of uses shown in lexicons and wordbooks (cf. Koehler \& Baumgartner 2001:1506-1510; Carr 1980:931). In verse 7 it is used in a construct formation with the city of Babylon and in combination with the verb 'to seek'. Most of the translations opt for the word 'welfare', meaning that what is favourable or beneficial to the city. It can also allude to the prosperity or success of the city. It also makes sense to urge the exiles to work for the peace and health (wellness) of the city (cf. Beck \& Brown 1976:777). Another possibility to consider is that the Judean exiles should not revolt and so cause trouble and frustration for the Babylonian authorities (Lundbom 2004:351). Keown, Scalise and Smothers (1995:720) argue a case that 'seeking the peace of the city' should be regarded as a warning to the Judean exiles not to revolt. They base their argument on the similarities between Deuteronomy 20:5-10 and Isaiah 65:21-23, two texts both reflecting war situations, with the wording in 29:5-7. Deuteronomy 20:10 also refers to the 'peace of the city'. Truth of the matter is that this use in verse 7 is open for interpretation, but the general gist of 'what is good or beneficial or healthy' to the city seems clear. The exiles in Babylon are commanded to actively seek and contribute to the welfare of the city. This is a call to actively advance the interests of the city in which they find themselves as exiles. This is clearly a call not to isolate themselves from life in the city, but to contribute to its well-being. What is not required is a passive presence, but an active and engaging presence, a presence that will make a difference to the city's welfare. Although the specifics of this command to action elude us, it is clearly a call for constructive engagement in the city's fate.

The relative clause in verse 7 should also not escape our attention. As was the case in verse 4 , it is once again repeated that the people of Judah find themselves in the city Babylon not by chance, but because of the action Yahweh took. Yahweh is responsible for their presence in Babylon (Allen 2008:323-324). It was their disobedience of the covenant stipulations and the disloyalty to the covenant relationship with Yahweh that resulted in their exile to Babylon. They are now instructed by their covenant God Yahweh to display a favourable attitude towards the welfare of the city and to heed obediently to his call to have a constructive presence in this foreign city.

In the final clause of verse 7 the exiles are instructed to intercede in prayer to Yahweh on behalf of the city. This is an interesting instruction since the people of Babylon did not believe in Yahweh, but worshipped their own gods. If they did act on the instruction to pray, it would be a sign of trust in Yahweh's ability to have an effect on people who do not even worship Yahweh. The prayer to Yahweh should be for the welfare or the prosperity of Babylon. The reasoning given is that if the inhabitants of Babylon experience healthy conditions and prosperity, it would create favourable mindsets amongst the city's inhabitants. If the citizens of Babylon experience Yahweh's favour, they would in-kind respond favourably towards the Judean exiles.

The frequent use of שָׁi seems to be deliberate, since the issue of 'peace' is a bone of contention in many of Jeremiah's confrontations with other prophetic figures and groups in his society. Jeremiah opposed the agents of peace prophecies in the face of the Babylonian threat as unauthorised messengers and prophets of deceit (cf. Jr 23:15-1 7; 28:2-4; 10, 15). The plea for שin in this context is ironic in the sense that the coveted peace promised by Jeremiah's opponents to Israel and Judah is now sought and prayed for to benefit their oppressors' city Babylon (cf. Allen 2008:320; also Brown 2010:358). But more than the fact that is desired for the city of Babylon, now the people who did not experience שָ in their own country, will experience it on foreign territory (Schmidt 2013:101). 
The call to seek and pray to Yahweh is also very significant. Whereas the temple in Jerusalem was the focal point for hearing the voice of Yahweh and seeking his will, now the call is to seek and pray whilst they are in a foreign country, away from their homeland. This implies that even in the faroff country of their exile, Yahweh can hear their prayers. This is a big shift in their theology moving away from the idea of a localised God (cf. Schmidt 2013:100). The theology of the exiles had to transform 'to focus on a universal deity who did not have to have a temple, to be present and worshipped' (Perdue \& Carter 2015:79). The exiles should know that Yahweh is present even when they are far away from their home country.

Davidson (2011:170) concludes that the letter in Jeremiah 29 delinks land from identity. He continues and says: 'This delinking moves identity away from being defined by turf and space to be defined by relationships, community, family, and religion'. I agree that these components would have helped the Judean people in establishing their identity in the new land and to survive in the foreign country. However to use such a strong term as 'delinking' in the sense of a clear cut or divide from the homeland cannot be made on the grounds of the limited information in 29:5-7. The 'reality prophecy' required the people to settle down for a lengthy period, but I am not convinced that that would have implied the relinquishing of the promise and hope of return and restoration in their homeland. In Jeremiah 32 the symbolic purchase of land suggests that Jeremiah had the expectation of a future for the people in their homeland. If 29:5-7 is interpreted to mean that Jeremiah suggested a permanent settlement in the new country, then this is not an oracle that is consistent with the view of Jeremiah from the book of Jeremiah, but from a different redactional strand in the book of Jeremiah.

From the discussion above, it is clear that the exiles should prepare themselves for a long stay in the foreign city of Babylon. This is the realistic prophetic word Jeremiah believes is from Yahweh (cf. Jones 1992:363). I do not regard the oracle in 29:4-7 simply as a pragmatic reaction to the political reality of the Babylonian domination, as it is a word from Yahweh proclaimed by Jeremiah to deal with the political reality. It is a response from a relationship with Yahweh the covenant God or as Brueggemann (1998:257) says: 'Prophetic faith is powerfully realistic about the political situation of the Jews in exile'. With this reality in mind the exiles should therefore patiently settle in Babylon and work constructively towards their future in this foreign country. They should not only take care of their own living conditions and future and isolate themselves from the local communities but should also contribute constructively to the welfare of the city. They should seek Yahweh's favour for the city, for their positive contribution to the city's welfare will work in their favour as well. Ames (2011) says:

The pragmatics of survival mold social structures. Extension and inclusion are grounded in the pragmatics of survival, and there are additional dynamics at work, including ideological dynamics. Human experience, social context, and physical environment transcend and shape ideological perspectives. The letter of Jeremiah links the welfare of the Judean and Babylonian enemies, but each, one assumes, has a stake in the security and prosperity of the other, and this promotes extension and inclusion. It fosters new identity and new ideals. Social need becomes theological perspective. (p. 184)

Strange as it may sound, they were called on to pray for Yahweh's favour on the heathen nation.

\section{Promise}

The promise of return and restoration always remained a desire of the people of Judah in exile. Jeremiah's message from Yahweh to patiently settle in the country of exile and to contribute positively to their exilic society by displaying a positive presence did not negate the promises of Yahweh. Fretheim (2002:402) says that the welfare of the exiles will reach completion when they are finally restored to their homeland. Jeremiah's message was that Jeremiah 29:11-14 will eventually come to fulfilment, ${ }^{7}$ but only after a long stay in the foreign country. Jeremiah's message reflected social and political realism.

\section{Isolated incident?}

The question can be asked whether the example of prophetic realism in Jeremiah 29:4-7 is an isolated incident in the ministry of the prophet Jeremiah. The answer is that there are other instances that could be regarded as examples of prophetic realism. One such example is Jeremiah 21:8-10 (cf. Wessels 2004:470-483). In this episode King Zedekiah sends a delegation consisting of Pashhur son of Malchiah and the priest Zephaniah son of Maaseiah to Jeremiah with the request to consult Yahweh about the threat posed by the Babylonian king Nebuchadnezzar to Jerusalem and its inhabitants. The king's expectation was a prophetic word of salvation that the Babylonian army would turn away. However the prophetic word came differently than expected and Jeremiah announced in verses 8-9 the following:

${ }^{8}$ And to this people you shall say: Thus says the LORD: See, I am setting before you the way of life and the way of death. ${ }^{9}$ Those who stay in this city shall die by the sword, by famine, and by pestilence; but those who go out and surrender to the Chaldeans who are besieging you shall live and shall have their lives as a prize of war. (Jr 21:8-9 NRS)

The message of realism that the prophet announced implied that the people could only survive if they surrendered to the Babylonian king. This was not the kind of prophetic proclamation that the people expected, therefore it was not received well. This example ties in with a more expanded version of Jeremiah's prophecy of realism in chapter 27 that only those who submit to the rule of king Nebuchadnezzar will survive (27:8, 11, 12-15).

7.It is highly debated whether 29:10-14 form part of the original letter. For some of the views on the matter, see Davidson (2011:146). Although redactional activities in the views on the matter, see Davidson (2011:146). Although redactional activities in
the Jeremiah text corpus cannot be denied, it should not be the easy way out when the Jeremiah text corpus cannot
interpretation challenges occur. 


\section{Conclusion}

In this article an effort was made to argue for a notion of prophetic realism. This was done by analysing and discussing Jeremiah 29:4-7. In the appeal of the prophet to the exiles to be realistic with regards to the Babylonian displacement and their immediate future, the call to them was to constructively engage their fate in the foreign country in a foreign city. ${ }^{8}$ The discussion was structured around the three aspects of patience, presence and promise. By showing this attitude they will experience some form of שָ in Babylon, the coveted שָׁלום so often promised by some prophets to come to fulfilment in their own country. Jeremiah's proclamation consisted of oracles of judgement and salvation, doom and hope, but to a great extent also oracles of prophetic realism. A final word, when one looks at Jeremiah 29 in terms of the distinction Nissinen (2004:31) makes between ancient Hebrew prophecy and biblical prophecy (prophecies interpreted by the writers of the text), then this chapter perhaps serves the purpose of justifying the reality of the existence of settled Judean communities in Babylon and Babylonian territory.

\section{Acknowledgements Competing interests}

The author declares that he has no financial or personal relationships which may have inappropriately influenced him in writing this article.

\section{References}

Albertz, R., 1994, A history of Israelite Religion, vol. 2, SCM, London.

Allen, L.C., 2008, Jeremiah, Westminster John Knox, Louisville, KY.

Ames, F.R., 2011, 'The cascading effects of exile: From diminished resources to new identities', in B.E. Kelle, F.R. Ames \& J.L. Wright (eds.), Interpreting exile. Displacement and deportation in Biblical and Modern contexts, pp. 173-187, Displacement and deportation in Biblity of Biblical Literature, Atlanta.
Societs

Beck, H. \& Brown, C., 1976, 'Peace', in C. Brown (ed.), Dictionary of New Testament theology, vol. 2, pp. 776-783, The Paternoster Press, Exeter.

8.It is interesting how the passage in Jeremiah $29: 4-7$ is applied in other theological disciplines to promote ideas about ministry. In an article on urban ministry in the USA, Rah (2013:55-69) uses this passage in Jeremiah to highlight two major points of which the first is to fall for the temptation to disengage the city and move thei interests to the suburbs. The second aspect is the temptation to look for quick fixes; See also in this regard the article Ekkert (1984:61-66). In an article on how churches can become missional, Macllvaine III (2010:222) discusses the potential of Jeremiah 29:4-7 as a model to be a missional church.
Bright, J., 1965, Jeremiah, Doubleday, New York.

Brown, M.L., 2010, 'Jeremiah', in T. Longman III \& D.E. Garland (eds.), Expositors Bible commentary Jeremiah-Ezekiel, pp. 21-572, Zondervan, Grand Rapids, MI.

Brueggemann, W., 1998, A commentary on Jeremiah. Exile \& homecoming, Eerdmans, Grand Rapids, MI.

Carr, G.L., 1980, 'Shalôm', in R.L. Harris, G.L. Archer Jr. \& B.K. Waltke, (eds.), Theological wordbook of the Old Testament, p. 931, Moody, Chicago, IL.

Carroll, R.P., 1986, Jeremiah, SCM, London.

Davidson, S.V., 2011, Empire and exile. Postcolonial readings of the book of Jeremiah, T\&T Clark, New York.

Diamond, A.R.P., 2003, 'Jeremiah', in J.D. Dunn \& J.W. Rogerson (eds.), Eerdmans commentary on the Bible, pp. 543-559, Eerdmans, Grand Rapids, MI.

Ekkert, H., 1984, 'Reconstruction our urban theology', Direction 13(1), 61-66.

Fischer, G., 2005, Jeremia 26-52, Verlag Herder, Freiburg.

Fretheim, T.E., 2002, Jeremiah, Smith \& Helwys, Macon, GA.

Huey, F.B., Jr., 1993, Jeremiah, Lamentations, Broadman Press, Nashville, TN.

Jones, D.R., 1992, Jeremiah, Eerdmans, Grand Rapids, MI.

Kautzsch, E., 1910, Gesenius' Hebrew grammar, 2nd English edn., Clarendon Press, Oxford.

Keown, G.L., Scarlise, P.J. \& Smothers, T.G., 1995, Jeremiah 26-25, Word Books, Dallas.

Koehler, L. \& Baumgartner, W., 2001, The Hebrew and Aramaic Lexicon of the Old Testament, Brill, Leiden.

Leuchter, M., 2008, The polemics of exile in Jeremiah 26-45, Cambridge University Press, Cambridge.

Lundbom, J.R., 2004, Jeremiah 21-36. A new translation with introduction and commentary, Doubleday, New York.

Macllvaine III, W. R., 2010, 'How churches become missional', Bibliotheca Sacra 167, 216-233.

McEntire, M., 2015, A chorus of prophetic voices. Introducing the prophetic literature of ancient Israel, Westminster John Knox, Louisville, KY.

Moberly, R.W.L., 2006, Prophecy and discernment, Cambridge University Press, Cambridge.

Nissinen, M., 2004, 'What is prophecy? An ancient near eastern perspective', in J. Kaltner \& L. Stulman (eds.), Inspired speech. Prophecy in the ancient near east. Essays in honour of H.B. Huffmon, pp. 17-37, T\&T Clark, London.

Osuji, A.C., 2010, Where is the truth? Narrative exegesis and the question of the true and false prophecy in Jer 26-29 (MT), Uitgeverij Peeters, Leuven.

Overholt, T.W., 1970, The treat of falsehood: A study in the theology of the book of Jeremiah, SCM, London.

Perdue, L.G. \& Carter, W., 2015, Israel and empire. A postcolonial history of Israel and early Judaism, Bloomsbury, London.

Rah, S-C., 2013, 'The necessity of lament for ministry in the urban context', Ex Auditu $29,55-69$.

Rudolph, W., 1968, Jeremia, 3rd enhanced edn., JCB Mohr, Tübingen.

Schmidt, W.H., 2013, Das Buch Jeremia, Kapitel 21-52, Vandenhoeck \& Ruprecht, Göttingen.

Smith-Christopher, D., 2002, A biblical theology of exile, Fortress, Minneapolis, MN

Thompson, J.A., 1980, The book of Jeremiah, Eerdmans, Grand Rapids, MI.

Weeks, S., 2010, 'Predictive and prophetic literature: Can Neferti help us read the Bible?' in J. 'Day (ed.), Prophecy and prophets in ancient Israel, pp. 25-46, T\&T Clark, London.

Weiser, A., 1969, Das Buch Jeremia, Vandenhoeck \& Ruprecht, Göttingen.

Wessels, W.J., 2004, 'Setting the stage for the future of the kingship: A critical reading of Jeremiah 21:1-10', Old Testament Essays 17(3), 470-483. 